\title{
ВЗАЕМОДІЯ ІЗОТРОПНОЇ НАНОЧАСТИНКИ З ДРЕЙФУЮЧИМИ ЕЛЕКТРОНАМИ У КВАНТОВІЙ ЯМІ
}

\author{
В.О. КОЧЕЛАП, С.М. КУХТАРУК
}

УДК 53.01, 53.04

(c) 2012

Інститут фізики напівпровідників ім. В.Є. Лашкарьова НАН України

(Просn. Науки, 41, Kиїв 03680; e-mail: kukhtaruk@gmail. com)

Розглянуто гібридні системи, що складаються з наночастинки та напівпровідникової гетероструктури з квантовою ямою. Наночастинка є такою, що поляризується у сторонньому електричному полі. Обгрунтовано та сформульовано модель гібридної системи. Отримано точні розв'язки рівнянь. Знайдені частоти коливань зарядів гібридної системи та їх додаткове загасання, що зумовлено взаємодією диполя з плазмонами. Природа додаткового загасання подібна до загасання Ландау. Проаналізовано поведінку в часі та просторі збурень концентрації двовимірних електронів. Досліджено поляризаційні коливання наночастинки. Знайдено, що при ненульових дрейфових швидкостях наведена поляризація характеризується складною динамікою. Зокрема, для двох із трьох гілок частотної дисперсії вектор поляризації обертається по еліптичних траєкторіях. У випадку, коли до квантової ями прикладене поле та тече струм, загасання змінюється на наростання коливань гібридної системи у часі, що відповідає електричній нестійкості гібридної системи. Нові явища в гібридних системах можуть бути застосовані для збудження випромінювання наночастинок струмом та для електричної генерації випромінювання в терагерцовій області спектра.

\section{1. Вступ}

Фізичні явища в терагерцовій $(\mathrm{THz})$ ділянці спектра активно досліджуються, що пов'язано із фундаментальною важливістю нової терагерцової фізики, а також із значною кількістю потенційно можливих використань. Зокрема метою багатьох досліджень є побудова нових джерел та детекторів $\mathrm{THz}$ випромінювання.

У цьому контексті великий інтерес викликають дослідження напівпровідникових гетероструктур 3 квантовими ямами $(\mathrm{QW})$, в яких можуть збуджува- тись колективні коливання двовимірних електронів (2DEG), тобто плазмони. Частоти коливань плазмонів знаходяться в $\mathrm{THz}$ ділянці спектра. В однорідному 2DEG плазмони є стійкими, тобто їх коливання загасають $з$ часом внаслідок розсіяння електронів на різноманітних дефектах кристала, а також через відомий механізм загасання Ландау. Для отримання ефектів нестійкості та наростання коливань з метою подальшого використання для підсилення та генерації $\mathrm{THz}$ випромінювання пропонувалися різні методи. Серед них розглядали можливість збудження нестійкості за рахунок дрейфу електронів в електричному полі [1-3], різні варіанти двопучкові нестійкості $[3,4]$, та інші. Проте для реалізації таких нестійкостей в просторово-однорідній плазмі потрібні дуже високі дрейфові швидкості, яких важко досягти на експерименті. Ситуація суттєво змінюється у просторово неоднорідних, або скінченних за розміром системах [5]. Наприклад, у роботах [6] було показано, що при використанні спеціальних типів контактів до квантової ями скінченної довжини, система електронів буде нестійкою вже при помірних дрейфових швидкостях електронів. Цю нестійкість було вивчено експериментально [7-9].

Іншим класом об'єктів, що є активними в $\mathrm{THz}$ області спектра, є квантові точки [10-13], молекули та деякі молекулярні сполуки [14-16], мілкі домішкові центри [17-19] тощо. Для стислості, такі "нульвимірні" об'єкти далі будемо називати наночастинками (NP).

Гібридні системи, що складаються 3 наночастинок та гетероструктур з вільними електронами, є новим типом гетеророзмірних об'єктів, які мають демонструвати принципово нові властивості та ефекти. 
Зокрема, якщо частоти коливань нульвимірних NP i двовимірних плазмонів потрапляють до $\mathrm{THz}$ діапазону спектра, для гібридних систем можна очікувати нові надвисокочастотні властивості. Тому своєчасним видається вивчення взаємодії таких NP з плазмонами в рівноважних та нерівноважних умовах.

У роботі [20] було розпочато дослідження віддаленої наночастинки 3 дрейфуючим 2DEG для відносно низьких частот, де $є$ правомірним застосування низькочастотного дрейфово-дифузійного наближення. У даній роботі наведено результати дослідження надвисокочастотних властивостей гібридних систем з використанням "високочастотного" наближення для розгляду руху електронів у 2DEG. Знайдено колективні коливання взаємодіючих наночастинки та 2DEG. Зокрема, визначені частоти спільних коливань та їх додаткове загасання, зумовлене взаємодією наночастинки з плазмонами. Загасання має характер, подібний до загасання Ландау. Показано, що при певних нерівноважних умовах така система є нестійкою: виникає індуковане електричним струмом наростання колективних коливань у часі. Присутність наночастинки руйнує трансляційну симетрію, внаслідок чого система є неоднорідною, що сприяє появі нестійкості, аналогічно до явищ, досліджених для неоднорідної чи просторово обмеженої плазми [5].

Структура роботи є такою. У розділі 2 обговорено модель гібридної системи та обгрунтовано основні рівняння. У розділі 3 отримано точні розв'язки рівнянь та досліджено загальні властивості цих розв'язків. У розділі 4 головну увагу приділено питанню стійкості/нестійкості гібридної системи в умовах дрейфу двовимірних електронів, наведено чисельні результати, розглянуто конкретні приклади наночастинок та гетероструктур 3 двовимірними електронами. Особливості узгоджених часово-просторових хвиль зарядів розглянуто в розділі 5. Властивості дипольного моменту NP, поля плазмонів та випромінювання гібридної системи досліджено в розділі 6. Узагальнюючі висновки наведено у розділі 7.

\section{2. Модель та основні рівняння}

Розглянемо гібридну систему, схематично зображену на рис. 1. Вона складається зі сферичної наночастинки, що поляризується у зовнішньому полі, та гетероструктури 3 квантовою ямою, в якій локалізовані двовимірні електрони. Відстань між наночастинкою та квантовою ямою позначається $h$. Електрони і на-

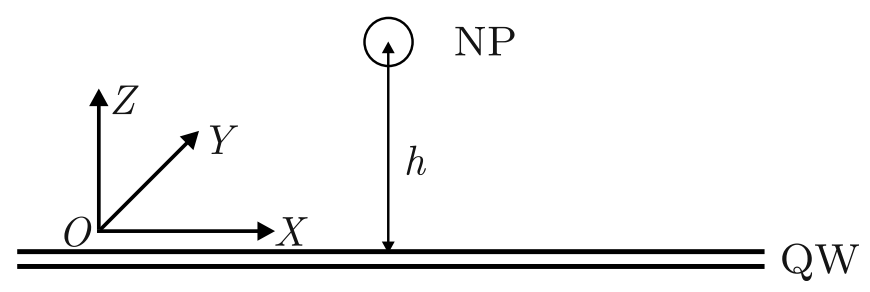

Рис. 1. Схематичне зображення гібридної системи. Вісь $O Y$ перпендикулярна до площини рисунка

ночастинка взаємодіють через електростатичне поле $\mathbf{E}=-\nabla \phi$, де $\phi(x, y, z, t)$ є самоузгоджений електростатичний потенціал, що визначається рівнянням Пуассона:

$\frac{\kappa}{4 \pi} \Delta \phi=e\left(n-n_{0}\right) \delta(z)+(\mathbf{D}(t) \nabla) \delta(x) \delta(y) \delta(z-h)$,

де $\kappa$ - діелектрична проникність, $e-$ заряд електрона, $n(x, y, t)$ - поверхнева концентрація електронів, $n_{0}$ - рівноважна поверхнева концентрація електронів, $\mathbf{D}(t)$ - електричний дипольний момент наночастинки, $\delta(x)$ - дельта-функція Дірака.

Скалярний потенціал зручно подати у вигляді двох доданків, що пов'язані з електронами та NP: $\phi(x, y, z, t)=\phi_{e}(x, y, z, t)+\phi_{d}(x, y, z, t)$, де $\phi_{e}$ та $\phi_{d}$ знаходимо з системи рівнянь:

$\left\{\begin{array}{l}\kappa \Delta \phi_{e}=4 \pi e\left(n-n_{0}\right) \delta(z), \\ \kappa \Delta \phi_{d}=4 \pi(\mathbf{D}(t) \nabla) \delta(x) \delta(y) \delta(z-h) .\end{array}\right.$

Для опису електронів у квантовій ямі (площина $z=0)$ використовуємо рівняння руху Ейлера та рівняння неперервності, які пов'язують поверхневу концентрацію $n(x, y, t)$ і швидкість електронів $\mathfrak{v}(x, y, t)$ з електростатичним полем. У загальному випадку вважаємо, що електрони рухаються із середньою дрейфовою швидкістю $\mathbf{v}_{\mathbf{0}}$. Тоді рівняння мають вигляд [6]:

$\left\{\begin{array}{l}\frac{\partial \mathfrak{v}}{\partial t}+\left(\mathfrak{v} \nabla_{\|}\right) \mathfrak{v}=\left.\frac{e}{m} \nabla \phi\right|_{z=0}-\frac{\mathfrak{v}-\mathbf{v}_{\mathbf{0}}}{\tau_{p}} \\ \frac{\partial n}{\partial t}+\nabla_{\|}(\mathfrak{v} n)=0\end{array}\right.$

де $e, m^{*}$ - заряд та ефективна маса електрона; за допомогою доданка $\frac{\mathfrak{v}-\mathbf{v}_{\mathbf{0}}}{\tau_{p}}$ враховано розсіяння електронів на дефектах кристала, $\tau_{p}$ - час релаксації імпульсу електронів. Індекс \| використано для величин та диференціальних операторів, які відносяться тільки до площини $z=0$. Наприклад, оператор Лапласа у площині $z=0$ позначається як $\Delta_{\|}=\frac{\partial^{2}}{\partial x^{2}}+\frac{\partial^{2}}{\partial y^{2}}$. Оператор Лапласа в об'ємі є $\Delta=\Delta_{\|}+\frac{\partial^{2}}{\partial z^{2}}$. Також будемо 
позначати дійсну та уявну частину комплексних чисел за допомогою штрихів, наприклад: $Z=Z^{\prime}+i Z^{\prime \prime}$.

У двовимірному електронному газі виникають колективні коливання густини заряду, які називаються плазмонами. Гідродинамічна модель з рівняннями (3) є справедливою, коли частота цих коливань $\omega$ та модуль хвильового вектора $k$ задовольняють умови

$\omega \tau_{p} \gg 1, \quad q l_{p} \sim l_{p} / h \gg 1$,

де $l_{p}$ - довжина вільного пробігу електронів. Оскільки в задачі присутній лише один характерний масштаб довжини - відстань $h$ між площиною 2DEG та NP, то можна очікувати, що хвильові вектори плазмонів, які вносять основний внесок у взаємодію між електронами та NP, є близько $1 / h$. Зауважимо, що нерівності (4) відповідають балістичному характеру руху електронів у просторовій області, що є актуальною для взаємодії наночастинки і плазмонів.

Припустимо, що швидкість електронів $\mathfrak{v}(x, y, t)=\mathbf{v}_{0}+\mathbf{v}(x, y) e^{-i \omega t}, \quad$ концентрація електронів $n(x, y, t)=n_{0}+n(x, y) e^{-i \omega t}$, причому $v \ll v_{0}$ та $n \ll n_{0}$. Нехай часові залежності потенціалів теж гармонічні: $\phi_{e}(x, y, z, t)=\varphi_{e}(x, y, z) e^{-i \omega t}$, $\phi_{d}(x, y, z, t)=\varphi_{d}(x, y, z) e^{-i \omega t}$. Частота $\omega$, що входить у ці формули, має бути знайдена з розв'язків рівнянь і є, взагалі кажучи, комплексною величиною, що відповідає загасаючим чи наростаючим у часі коливанням гібридної системи (у випадку $\omega^{\prime \prime}>0$ в системі наявна нестійкість і $\omega^{\prime \prime}$ називають інкрементом нестійкості). Величини $\mathbf{v}(x, y), n(x, y)$ описують просторові залежності збурень швидкості та концентрації електронів відповідно.

Наночастинка розміщена відповідно до рис. 1 в точці $x=0, y=0, z=h$. У сторонньому електричному полі вона поляризується і може бути охарактеризована електричним дипольним моментом, який визначається співвідношенням

$\mathbf{D}(t)=\mathbf{d}(\omega) e^{-i \omega t}$,

$\mathbf{d}(\omega)=-\left.\beta_{0}(\omega) \nabla \varphi_{e}\right|_{x=y=0, z=h}$,

де $\beta_{0}(\omega)$ - поляризовність наночастинки. Зауважимо, що у співвідношення (5) входить тільки потенціал електронів i, таким чином, виключається самодія диполя. У випадку ізотропної наночастинки поляризовність може бути подана у стандартному вигляді [21]:

$\beta_{0}(\omega)=-\sum_{f} \frac{2 \omega_{f} e^{*^{2}}}{\hbar} \frac{|\langle f|x| 0\rangle|^{2}}{\omega^{2}-\omega_{f}^{2}+i \omega / \tau_{f}}$ де $\hbar$ - зведена стала Планка, $\hbar \omega_{f}$ - енергія $f$-го рівня наночастинки, $\tau_{f}-$ час життя цього рівня, $\langle f|x| 0\rangle$ $\epsilon$ матричним елементом дипольного переходу між основним та $f$-м збудженим станом.

$\mathrm{У}$ поляризовність (6) найбільший внесок вносить перехід між основним та першим збудженим станами. У цьому випадку поляризовність має вигляд

$\beta_{0}(\omega)=-\frac{e^{*^{2}}}{\hbar} \frac{|\langle 1|x| 0\rangle|^{2}}{\omega-\omega_{0}+i \gamma_{0}}$,

де введено власну частоту коливання диполя $\omega_{0}$ та власне загасання його коливань $\gamma_{0}=1 /\left(2 \tau_{1}\right)$, які відповідають переходу між основним та першим збудженим станами. При отриманні формули (7) зроблено припущення, що $\omega$ близька до $\omega_{0}$, оскільки основні ефекти очікуються при частотах близьких до власної частоти коливання диполя.

Сукупність рівнянь (1)-(3), (5) та (7) становить систему основних рівнянь розв'язуваної задачі.

\section{3. Розв'язки рівнянь та їх загальні властивості}

Потенціал диполя, який є розв'язком другого рівняння Пуассона з системи (2), має добре відомий вигляд

$\varphi_{d}=\frac{1}{\kappa} \frac{d_{x}(\omega) x+d_{y}(\omega) y+d_{z}(\omega)(z-h)}{\left(x^{2}+y^{2}+(z-h)^{2}\right)^{\frac{3}{2}}}$,

де $d_{x}, d_{y}, d_{z}$ - компоненти дипольного моменту $\mathbf{d}(\omega)$. Надалі для всіх величин, що залежать від координат, будемо використовувати двовимірне перетворення Фур'є:

$\varphi_{e}(\mathbf{r}, z)=\int d^{2} k \varphi_{k}(z) e^{i \mathbf{k r}}$,

$n(\mathbf{r})=\int d^{2} k n_{k} e^{i \mathbf{k r}}, \quad \psi(\mathbf{r})=\int d^{2} k \psi_{k} e^{i \mathbf{k r}}$,

де $\mathbf{r}=(x, y), \mathbf{k}=\left(k_{x}, k_{y}\right), \psi(\mathbf{r})=\left.\varphi_{d}(\mathbf{r}, z)\right|_{z=0}$. Величини $\varphi_{k}(z), n_{k}$ та $\psi_{k} \epsilon$, відповідно, фур'є-образами потенціалу електронів, поверхневої концентрації та потенціалу, що індукується диполем у площині квантової ями $(z=0)$. Тоді рівняння Пуассона для $\varphi_{k}(z)$ i необхідні граничні умови матимуть вигляд

$$
\left\{\begin{array}{l}
\frac{d^{2} \varphi_{k}^{ \pm}}{d z^{2}}-k^{2} \varphi_{k}^{ \pm}=0, \\
\left.\varphi_{k}^{ \pm}\right|_{z \rightarrow \pm \infty} \rightarrow 0, \\
\left.\varphi_{k}^{+}\right|_{z=0+\varepsilon}=\left.\varphi_{k}^{-}\right|_{z=0-\varepsilon}, \\
\left.\frac{d \varphi_{k}^{+}}{d z}\right|_{z=0+\varepsilon}-\left.\frac{d \varphi_{k}^{-}}{d z}\right|_{z=0-\varepsilon}=\frac{4 \pi e n_{k}}{\kappa},
\end{array}\right.
$$


де $\varphi_{k}^{+}(z)=\varphi_{k}(z)$ при $z \geq 0$, а $\varphi_{k}^{-}(z)=\varphi_{k}(z)$ при $z \leq 0 ; k=\sqrt{k_{x}^{2}+k_{y}^{2}}$, величина $\varepsilon \rightarrow+0$.

Розв'язок системи (11), а також функції $\psi_{k}$ та $n_{k}$, мають вигляд

$$
\left\{\begin{array}{l}
\varphi_{k}=-\frac{2 \pi e n_{k}}{\kappa k} e^{-k|z|} \\
\psi_{k}=-\frac{1}{2 \pi \kappa}\left(i \frac{d_{x} k_{x}+d_{y} k_{y}}{k}+d_{z}\right) e^{-k h} \\
n_{k}=-\frac{e n_{0} k^{2}}{m} \frac{\left.\varphi_{k}\right|_{z=0}+\psi_{k}}{\left(\omega-\mathbf{v}_{\mathbf{0}} \mathbf{k}\right)\left(\omega-\mathbf{v}_{\mathbf{0}} \mathbf{k}+i / \tau_{p}\right)} .
\end{array}\right.
$$

Зауважимо, що у граничному випадку, який відповідає нескінченному віддаленню диполя від 2DEG $(h \rightarrow \infty)$, з розв'язків $(12)$ легко отримати закон дисперсії колективних збуджень дрейфуючого 2DEG, тобто дрейфуючих плазмонів:

$\omega_{ \pm}=\mathbf{v}_{\mathbf{0}} \mathbf{k} \pm \sqrt{\frac{2 \pi e^{2} n_{0}}{\kappa m} k-\frac{\gamma_{p}^{2}}{4}}-\frac{i \gamma_{p}}{2}$,

де позначено $\gamma_{p}=1 / \tau_{p}$. 3 іншого боку, нулі знаменника $\beta_{0}(\omega)(7)$ відповідають частоті і загасанню диполя: $\omega=\omega_{0}-i \gamma_{0}$.

При скінченній відстані $h$ з системи (12) та співвідношень (5) і (7) можна отримати інтегральне рівняння, наприклад, для фур'є-образу концентрації електронів, які взаємодіють з диполем:

$n_{k}=-\frac{e^{2} n_{0}}{\kappa^{2} m} \frac{\beta_{0}(\omega) k e^{-k h}\left(k_{x} I_{x}+k_{y} I_{y}+k I_{z}\right)}{\left(\omega-\mathbf{v}_{\mathbf{0}} \mathbf{k}\right)\left(\omega-\mathbf{v}_{\mathbf{0}} \mathbf{k}+i \gamma_{p}\right)-\frac{2 \pi e^{2} n_{0} k}{\kappa m}}$,

де $I_{x}, I_{y}, I_{z}$ є функціоналами $n_{k}$ :

$I_{x}=\int d^{2} q \frac{q_{x}}{q} n_{q} e^{-q h}, I_{y}=\int d^{2} q \frac{q_{y}}{q} n_{q} e^{-q h}, I_{z}=\int d^{2} q n_{q} e^{-q h}$.

Якщо позначити

$B_{0}=-\frac{e^{2} n_{0}}{\kappa^{2} m} \beta_{0}(\omega)$,

$\Delta_{e}(\omega, k)=\left(\omega-\mathbf{v}_{\mathbf{0}} \mathbf{k}\right)\left(\omega-\mathbf{v}_{\mathbf{0}} \mathbf{k}+i \gamma_{p}\right)-\frac{2 \pi e^{2} n_{0} k}{\kappa m}$

то з інтегрального рівняння (14) можна отримати таку систему алгебраїчних рівнянь:

$\left\{\begin{array}{l}I_{x}=B_{0}\left(S_{x} I_{x}+S_{0} I_{z}\right), \\ I_{y}=B_{0} S_{y} I_{y}, \\ I_{z}=B_{0}\left(S_{0} I_{x}+S_{z} I_{z}\right),\end{array}\right.$ де введено позначення для інтегралів, що можуть бути обчислені:

$S_{x}=\int \frac{d^{2} k k_{x}^{2} e^{-2 k h}}{\Delta_{e}(\omega, k)}, S_{y}=\int \frac{d^{2} k k_{y}^{2} e^{-2 k h}}{\Delta_{e}(\omega, k)}$,

$S_{z}=\int \frac{d^{2} k k^{2} e^{-2 k h}}{\Delta_{e}(\omega, k)}, S_{0}=\int \frac{d^{2} k k_{x} k e^{-2 k h}}{\Delta_{e}(\omega, k)}$.

Зауважимо, що параметр $S_{0}=0$, якщо дрейф електронів відсутній $\left(\mathbf{v}_{\mathbf{0}}=0\right)$.

Рівність нулю детермінанта системи рівнянь (15) є умовою існування нетривіальних розв'язків інтегрального рівняння (14). Цю умову, що визначає частоту $\omega$, будемо називати дисперсійним рівнянням. Якщо дрейфова швидкість електронів направлена вздовж осі $O X$, то дисперсійне рівняння має вигляд

$\left[\left(1-B_{0} S_{x}\right)\left(1-B_{0} S_{z}\right)-B_{0}^{2} S_{0}^{2}\right]\left[1-B_{0} S_{y}\right]=0$.

Дисперсійне рівняння (17) описує всі можливі спільні коливання електронів та диполя. За умов рівноважного стану електронів $\left(\mathbf{v}_{\mathbf{0}}=0, S_{0}=0\right)$ дисперсійне рівняння розпадається на три рівняння $\left(1-B_{0} S_{x}\right)=0,\left(1-B_{0} S_{y}\right)=0,\left(1-B_{0} S_{z}\right)=0$, розв'язки кожного з яких відповідають різним орієнтаціям індукованого диполя. Очевидно, що розв'язки рівнянь (частоти спільних коливань диполя та електронів), що відповідають $x$-й та $y$-й орієнтації диполя, будуть однакові, оскільки за відсутності дрейфу носіїв заряду ці два напрямки є фізично еквівалентними. Частота спільних коливань при $z$-й орієнтації буде, взагалі кажучи, відрізнятись від частот, що відповідають $x$-й та $y$-й орієнтації диполя.

У загальному випадку рівняння (17) факторизується до двох окремих рівнянь. Одне з них є рівняння

$\left(1-B_{0} S_{x}\right)\left(1-B_{0} S_{z}\right)=B_{0}^{2} S_{0}^{2}$.

Можна легко переконатися, що для частот, які $\mathrm{\epsilon}$ розв'язками цього рівняння, електричне поле електронів має таку симетрію, при якій індукований диполь наночастинки лежить у площині $x-z$, тобто відповідає змішаній $x-z$ орієнтації. Коренями цього рівняння є дві частотні гілки. Ту гілку, яка при $v_{0}=0$ відноситься до $x$-ї орієнтації диполя (тобто визначається з рівняння $B_{0} S_{x}=1$ ) будемо називати $x$-ю. Іншу гілку, відповідно, $z$-ю. Як і у випадку рівноваги $\left(v_{0}=0\right)$, розв'язки рівняння

$B_{0} S_{y}=1$ 
відповідають орієнтації диполя паралельно осі $O Y$ для будь-яких значень $v_{0}$, тому відповідну частотну гілку будемо називати $y$-ю.

Розв'язки дисперсійного рівняння (17) можна подати так:

$\Omega_{j}=\Omega_{0}-i \Gamma_{0}+\frac{\Lambda}{\Omega_{0}} R_{j}\left(V_{0}, \Omega_{j}, \Gamma_{p}\right)$,

де індекс $j=x, y, z$ позначає $x$-ву, $y$-ву та $z$-ву гілки. Також позначено

$\Omega_{j}=\frac{\omega_{j}}{\omega_{p l}}, \quad \omega_{p l}=\sqrt{\frac{2 \pi e^{2} n_{0}}{\kappa m h}}, \quad V_{0}=\frac{v_{0}}{\omega_{p l} h}$,

$\Omega_{0}=\frac{\omega_{0}}{\omega_{p l}}, \quad \Gamma_{0}=\frac{\gamma_{0}}{\omega_{p l}}, \quad \Gamma_{p}=\frac{1}{2 \gamma_{p} \omega_{p l}}$,

$\Lambda=\frac{e^{2} e^{*^{2}} n_{0}|\langle 1|x| 0\rangle|^{2}}{\kappa^{2} m h^{4} \hbar \omega_{p l}^{4}}$.

Параметр $\Lambda$ відповідає за зв'язок між 2DEG та диполем, $R_{j}\left(V_{0}, \Omega_{j}, \Gamma_{p}\right)$ - деяка комплексна функція від дрейфової швидкості електронів, частоти коливань диполя та загасання плазмонів. Для $x, z$ гілок вираз для функції $R_{x, z}$ має вигляд

$R_{x, z}=\frac{1}{2}\left[S_{x}+S_{z} \pm\left(S_{x}-S_{z}\right) \sqrt{1+\left(\frac{2 S_{0}}{S_{x}-S_{z}}\right)^{2}}\right]$

де знак плюс відповідає $x$-й гілці частоти, а мінус - $z$ й гілці. Для $y$ гілки легко отримати простіший вираз

$R_{y}=S_{y}$.

Дійсна частина цієї функції $R_{j}^{\prime}$ описує зсув частоти коливання системи відносно власної частоти диполя за рахунок взаємодії диполя та електронів. Уявна $R_{j}^{\prime \prime}$ відповідає за додаткове загасання (чи наростання) коливань гібридної системи.

3 аналізу інтегралів (16) випливає, що в надвисокочастотному випадку (4) функції $R_{j}$ практично не залежать від параметра $\Gamma_{p}$. (В гідродинамічному наближенні, що використовується в цій роботі, загасання плазмонів визначається виключно одночастинковою релаксацією електронів. При цьому загасання Ландау для плазмонів, що виникає при кінетичному розгляді електронів, [22] вважається малим.) За відсутності дрейфу електронів можна аналітично показати, що у випадку $\Gamma_{p} \rightarrow 0$ :

$$
R_{x, y}=\pi \mathcal{P} \int d k \frac{k^{3} e^{-2 k}}{\Omega_{x, y}^{2}-k}-i \pi^{2} \Omega_{x, y}^{6} e^{-2 \Omega_{x, y}^{2}},
$$

$R_{z}=2 R_{x, y}$

Причиною виникнення ненульової $R_{j}^{\prime \prime}$ i, відповідно, загасання коливань гібридної системи є колективна взаємодія аналогічна ефекту загасання Ландау [22]. Справді, завдяки неперервності спектра плазмонів (13) для заданої частоти $\omega_{0}$ завжди знайдуться "peзонансні" плазмони, зарядові хвилі яких пропорційні $\exp \left[i\left(\mathbf{k}_{\mathbf{r}} \mathbf{r}-\omega t\right)\right]$ з хвильовими векторами, що задовольняють умову $\omega^{ \pm}\left(\mathbf{k}_{\mathbf{r}}\right)=\omega_{0}$. В той же час, електричне поле диполя є сумою Фур'є компонент $\mathbf{E}_{d, \mathbf{k}} \exp \left[i \mathbf{k r}-i \omega_{0} t\right]$, включно з $\mathbf{k}=\mathbf{k}_{r}$. Хвилі дипольного поля з хвильовими векторами $\mathbf{k}_{r}$ та "резонансні" плазмони є сфазованими і поширюються з однаковою швидкістю. Це означає, що відповідне дипольне поле діє стало (без зміни у часі) на заряди "резонансних" плазмонів. У результаті робота дипольного поля над зарядами є ненульовою, і диполь втрачає свою енергію. За нерівноважних умов диполь може набувати енергію від електронної підсистеми. Необхідною умовою для цього $є$

$R_{j}^{\prime \prime}\left(V_{0}, \Omega_{j}, \Gamma_{p}\right)>0$

Достатня умова нестійкості гібридної системи в цілому є більш жорсткою:

$\frac{\Lambda}{\Omega_{0}} R_{j}^{\prime \prime}\left(V_{0}, \Omega_{j}, \Gamma_{p}\right)>\Gamma_{0}$.

У випадку оберненої нерівності система є або стійкою, або коливання системи загасають.

\section{4. Взаємодія мілкого донора з дрейфуючими двовимірними електронами}

У цьому розділі ми застосуємо отримані вище результати до конкретної гібридної системи, що складається з мілкого домішкового центру та гетероструктури 3 квантовою ямою.

Добре відомо, що одночастинкові кулонівські домішки у напівпровідниках мають малі енергії зв'язку та дозволені дипольні фотопереходи між станами домішки в ТГц ділянці спектра. Такі домішки можна розглядати як воднеподібний атом, енергетичний спектр та хвильові функції якого можуть бути розраховані в наближенні ефективної маси (див., наприклад, [23]). Різниця енергії основного $(1 S)$ та збудженого $(2 P)$ станів оцінюеться як $E_{S-P}=3 e^{2} / 8 \kappa a_{B}$, де $a_{B}=\kappa \hbar^{2} / m e^{2}-$ радіус основного стану. Наприклад, для GaAs $3 m=0,067 m_{0}, \kappa=12,9\left(m_{0}-\right.$ маса вільного електрона) ми отримуємо $E_{S-P} \approx 4,12$ 

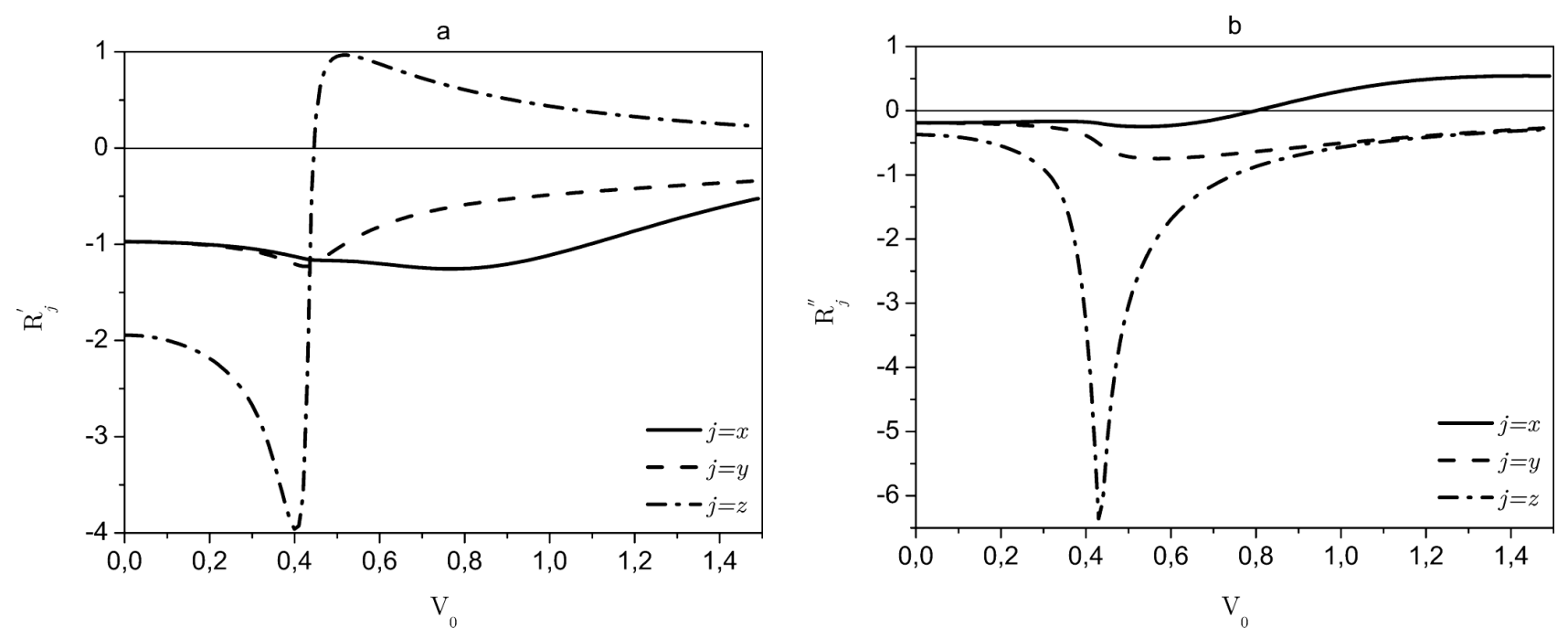

Рис. 2. Залежність дійсної $(a)$ та уявної $(b)$ частини функції $R_{j}$ від дрейфової швидкості електронів при фіксованій частоті диполя $\left(\Omega_{0} \approx 0,58\right)$. Інші параметри наведено у тексті

меВ, $a_{B} \approx 10$ нм. Ця різниця енергій відповідає частоті $\omega_{0} \approx 6,2 \cdot 10^{12} \mathrm{c}^{-1}(\approx 0,99$ ТГц). Фотоперехід $S \leftrightarrow P$ є дипольно дозволеним з матричним елементом переходу $\langle 1|x| 0\rangle \approx 0,52 a_{B}^{*}$. Ці параметри дозволяють побудувати поляризовність кулонівської домішки згідно зі співвідношенням (7).

Для того щоб досягнути умов збудження нестійкості, потрібно вибрати матеріал гетероструктури, що характеризується високими швидкостями електронів. Ми розглянемо квантову яму на основі InAs з бар'єрами GaAs. Як відомо з [24], в матеріалі InAs ефективна маса електронів мала, $m \approx 0,023 \cdot m_{0}$, а рухливість велика навіть при кімнатній температурі $\mu \approx 8 \cdot 10^{4}$ $\mathrm{cm}^{2} /(\mathrm{B} \cdot \mathrm{c})$. Це забезпечує реалізацію дуже високих дрейфових швидкостей електронів, аж до $v_{0} \approx 6 \cdot 10^{7}$ cм/с $[24,25]$. У квантових ямах на основі InGaAs матеріалів спостерігаються дрейфові швидкості того ж порядку. Різницею в діелектричних сталих квантової ями та бар'єра можна нехтувати [20]. Для числових розрахунків ми виберемо фізичні параметри так, щоб виконувались критерії (4). Зокрема, зафіксуємо концентрацію електронів $n_{0}=10^{11} \mathrm{~cm}^{-2}$ та відстань від 2DEG до донора $h=4 \cdot 10^{-6}$ см. Характерні параметри, що введені співвідношеннями (19), дорівнюють: $\omega_{p l} \approx 1,07 \cdot 10^{13} \mathrm{c}^{-1}, \Lambda \approx 0,0013, \Gamma_{p} \approx 0,03$. Швидкість дрейфу носіїв нормується на величину $\omega_{p l} h \approx 4,28 \cdot 10^{7} \mathrm{~cm} / \mathrm{c}$.

На рис. 2,3 наведено залежності дійсної $R_{j}^{\prime}$ та уявної $R_{j}^{\prime \prime}$ частини функції $R_{j}$ від нормованих швидкості $V_{0}$ та частоти $\Omega_{0}$, відповідно. 3 рис. $2, a$ та $3, a$ видно, що для вибраних фіксованих параметрів відбу- вається невеликий (у порівнянні $\left.з \omega_{0}\right)$ зсув частоти коливання системи в бік їі зменшення для $x$-ї та $y$-ї частотних гілок та зсув в обидва боки для $z$-ї гілки. 3 рис. 2 видно, що $R_{x}^{\prime \prime}$ змінюе знак починаючи 3 $V_{0} \approx 0,8$, що відповідає значенню дрейфової швидкості $v_{0} \approx 3,4 \cdot 10^{7} \mathrm{~cm} / \mathrm{c}$. Якщо при цьому буде виконана умова (22), то має виникнути нестійкість і наростання коливань системи. Також видно, що при достатньо малих дрейфових швидкостях $x$-ва та $y$-ва гілки зливаються, що пов'язано з еквівалентністю цих напрямків при $V_{0} \rightarrow 0$. Як показано на рис. 3 , чим менша частота коливання диполя, тим більший інкремент нестійкості. Що стосується $y$-ї та $z$-ї гілок, то для розглянутого діапазону частот та дрейфових швидкостей $R_{y}^{\prime \prime}<0$ та $R_{z}^{\prime \prime}<0$, тому відповідні коливання системи загасають.

У роботах [17-19] показано, що донорні електрони на мілких донорах в $\mathrm{GaAs}$ можуть мати обернений час життя близько $10^{7} \mathrm{c}^{-1}$. У випадку коли $V_{0} \approx 0,94$ та $\Omega_{0} \approx 0,58$ ми отримуємо $\frac{\Lambda}{\Omega_{0}} R_{x}^{\prime \prime} \omega_{p l} \approx 5,28 \cdot 10^{9} \mathrm{c}^{-1}$. $\mathrm{У}$ такому випадку критерій (22) добре виконується, i вказані ефекти нестійкості мають спостерігатися для аналізованої гібридної системи. Зауважимо, що збільшення концентрації електронів або відстані $h$ приводить до зменшення інкремента нестійкості, оскільки $\Lambda \propto n_{0}^{-1}$ та $\Lambda \propto h^{-2}$. Також було перевірено, що всі ефекти слабо залежать від параметра $\Gamma_{p}$

Таким чином, на прикладі InAs квантової ями та мілкого воднеподібного донора в бар'єрі GaAs показано, що для $x$-ї гілки спільних коливань в системі може 

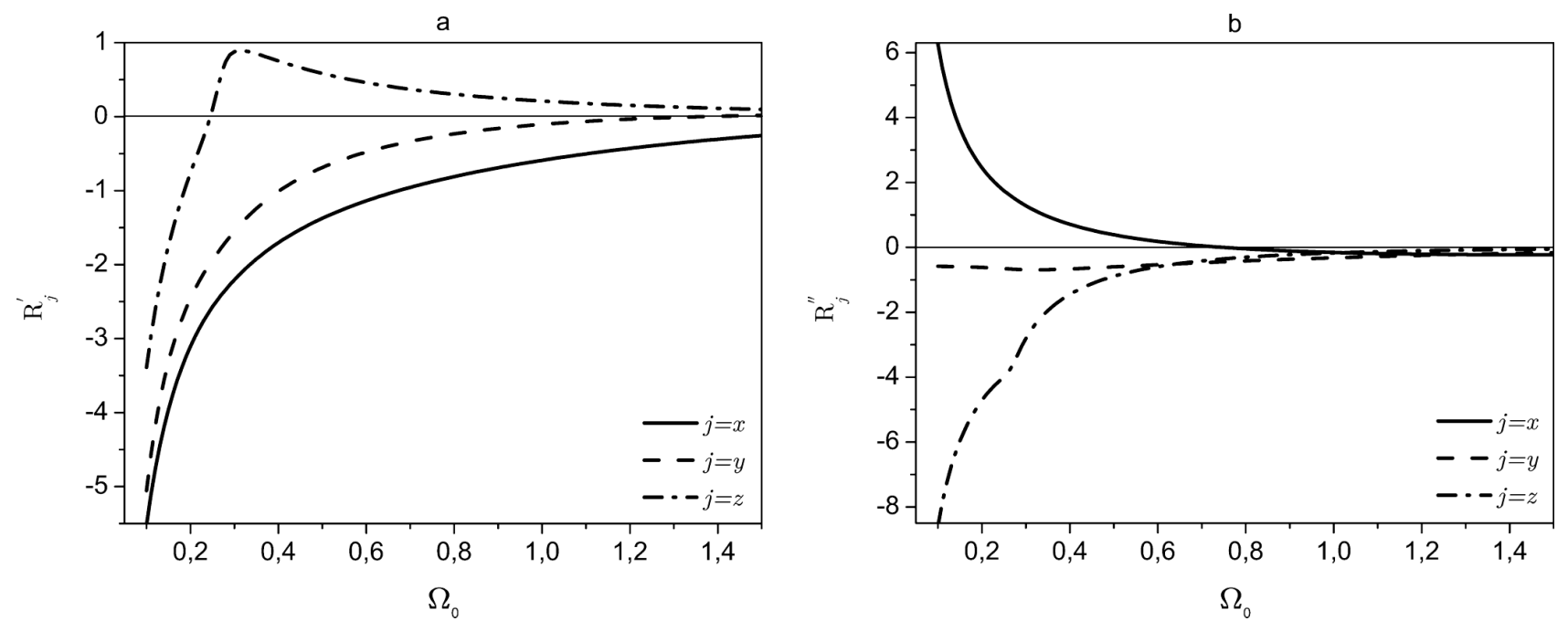

Рис. 3. Залежність дійсної та уявної частини функції $R_{j}$ від частоти $\Omega_{0}$ при фіксованій дрейфовій швидкості $V_{0} \approx 0,94$. Інші параметри наведено у тексті

мати місце нестійкість. Коливання, які відповідають двом іншим $y$ - та $z$-частотним гілкам, загасають.

\section{5. Зарядові хвилі}

У попередніх розділах виведено і розглянуто дисперсійне рівняння для спільних коливань диполя та 2DEG. Його розв'язками є власні частоти (власні значення) коливань системи. У цьому розділі побудовано власні функції, що відповідають цим власним значенням і є розв'язками інтегрального рівняння (14). Аналіз розв'язків дозволяє зрозуміти поведінку електронної підсистеми при колективних коливаннях.

Нагадаємо, що інтегральне рівняння для концентрації носіїв $n_{k}(14)$ конкретизується для відповідного типу спільних коливань, коли знайдені розв'язки алгебраїчної системи (15) для $I_{x}, I_{y}, I_{z}$, що є функціоналами $n_{k}$. Для двох змішаних $x-z$ орієнтацій диполя величина $I_{y}$ є тотожний нуль. Тоді з першого і третього рівняння цієї системи легко отримати

$I_{z}=K_{x} I_{x}=K_{z}^{-1} I_{x}$

де позначено: $K_{x}=B_{0} S_{0} /\left(1-B_{0} S_{z}\right), K_{z}=B_{0} S_{0} /(1-$ $-B_{0} S_{x}$ ) (в цих позначеннях дисперсійне рівняння для $x$-ї та $z$-ї гілки запишуться як $K_{x} K_{z}=1$.) Тоді розв'язок лінійного інтегрального рівняння (14), що відповідає $x$-й гілці частоти має вигляд

$n_{k}^{(x)}=C B_{0} \frac{k\left(k_{x}+K_{x} k\right)}{\Delta_{e}\left(\omega_{x}, k\right)} e^{-k h}$,

де індекс у дужках у величини $n_{k}^{(x)}$ означає, що частота, яка входить у величини $B_{0}, K_{x}$ та $\Delta_{e}$ належить $x$-й гілці. Взагалі константа $C$ є довільною комплексною величиною, що має амплітуду та фазу. Остання є несуттєвою, бо за рахунок зміни початку відліку часу її можна завжди зробити нульовою. Тому нижче вважатимемо $C$ дійсним числом.

Підставивши (23) в формулу для перетворення Фур'є, отримаємо часово-просторовий розподіл збурення концентрації:

$n^{(x)}(\mathbf{r}, t)=C B_{0} \int d^{2} k \frac{k\left(k_{x}+K_{x} k\right)}{\Delta_{e}\left(\omega_{x}, k\right)} e^{-k h+i \mathbf{k r}-i \omega_{x} t}$.

Фізичний зміст має дійсна частина (24). Позначимо

$J_{x}(\mathbf{r})=C B_{0} \int d^{2} k \frac{k k_{x}}{\Delta_{e}\left(\omega_{j}, k\right)} e^{-k h+i \mathbf{k r}}$,

$J_{z}(\mathbf{r})=C B_{0} \int d^{2} k \frac{k^{2}}{\Delta_{e}\left(\omega_{j}, k\right)} e^{-k h+i \mathbf{k r}}$

та $\tau_{j}=\omega_{j}^{\prime} t$, де для $x$-ї частотної гілки $j=x$. Виділяючи дійсну частину збурення концентрації (24), отримуємо

$n^{\prime(x)}\left(\mathbf{r}, \tau_{x}\right)=$

$=e^{\frac{\omega_{x}^{\prime \prime}}{\omega_{x}^{\prime}} \tau_{x}}\left[\left(J_{x}^{\prime}(\mathbf{r})+K_{x}^{\prime} J_{z}^{\prime}(\mathbf{r})-K_{x}^{\prime \prime} J_{z}^{\prime \prime}(\mathbf{r})\right) \cos \tau_{x}+\right.$

$\left.+\left(J_{x}^{\prime \prime}(\mathbf{r})+K_{x}^{\prime} J_{z}^{\prime \prime}(\mathbf{r})+K_{x}^{\prime \prime} J_{z}^{\prime}(\mathbf{r})\right) \sin \tau_{x}\right]$ 

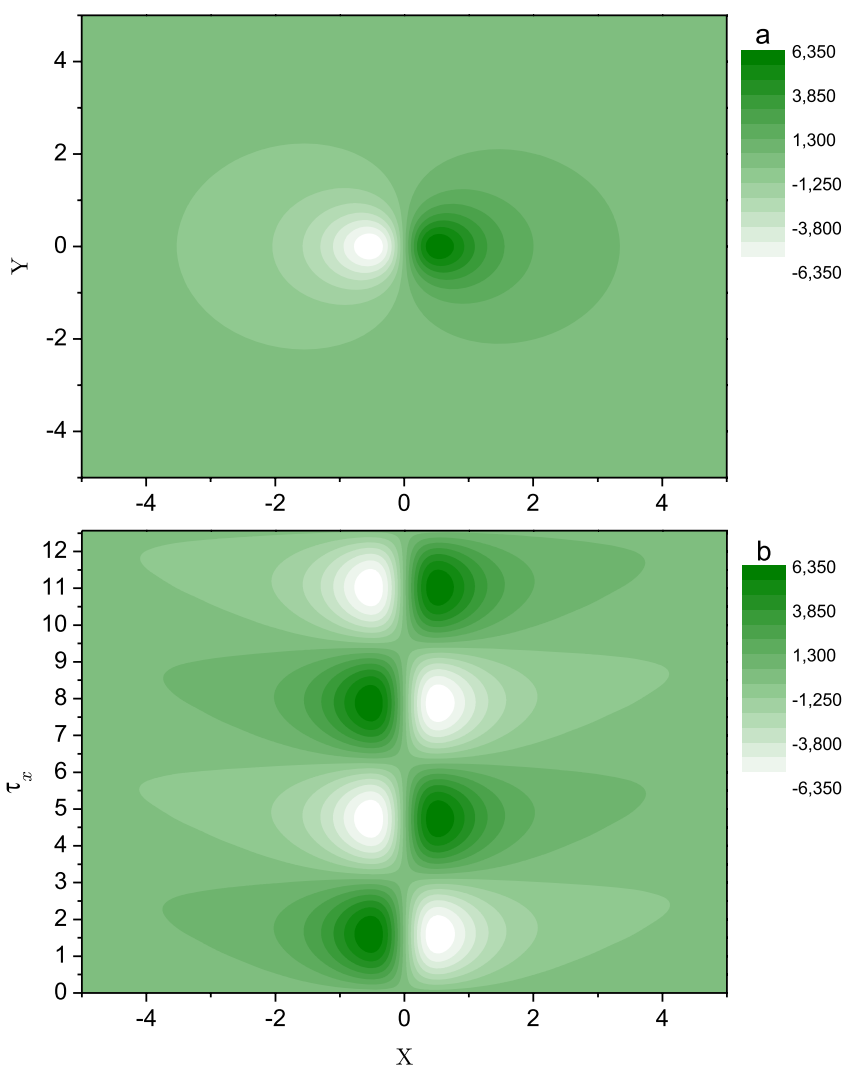

Рис. 4. Контури просторово-часових залежностей збурень концентрації електронів при $V_{0}=0$, що відповідають $x$-й гілці частоти: $a-$ просторова залежність при $\tau_{x}=\frac{3 \pi}{2} ; b-$ просторовочасова залежність при $Y=0$

Властивості розв'язків (25) є такими. Функція $n^{\prime(x)}\left(\mathbf{r}, \tau_{x}\right)$, як і $n^{(x)}(\mathbf{r}, t) \in$ парною по $y$. Оскільки $\frac{\omega_{x}^{\prime \prime}}{\omega^{\prime}} \ll 1$, то амплітуда цієї функції мало змінюється в межах декількох періодів. При $V_{0}=0$ ця функція $є$ непарною функцією координати $x$. Взагалі $n^{\prime(x)}\left(\mathbf{r}, \tau_{x}\right)$ описує поведінку зарядових хвиль в двовимірному просторі та у часі.

На рис. 4 зображено контури просторових та часових залежностей збурення концентрації електронів, що відповідають $x$-й гілці частоти (в цьому випадку диполь орієнтований паралельно осі $O X$ ), за відсутності дрейфу електронів $\left(V_{0}=0\right)$. Зокрема на рис. 4, $a$ проілюстровано просторовий розподіл концентрації в момент часу $\tau_{x}=3 \pi / 2$, який має мінімум та максимум, відповідно, ліворуч та праворуч від початку координат, де розташований диполь. Такий розподіл виник через відповідне розташування зарядів диполя в фіксований момент часу. На часовопросторовій ілюстрації рис. $4, b$ видно, що ці максимуми і мінімуми змінюють один одного в часі з періодом
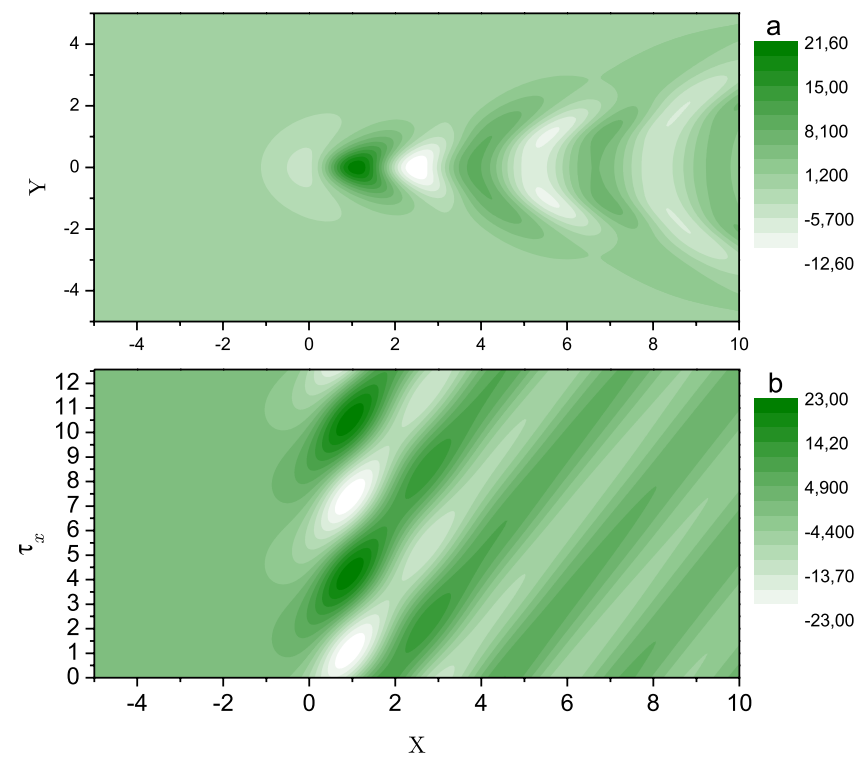

Рис. 5. Теж саме, що на рис. 4 , але при $V_{0} \approx 0,94$

$\pi$. Просторовий масштаб збурення є близько декількох $h$.

Контури просторових та часових залежностей концентрації електронів в умовах дрейфу електронів вздовж осі $O X\left(V_{0} \approx 0,94\right)$ зображено на рис. 5 . При наявності дрейфу, в загальному випадку диполь орієнтується у площині $y=0$ (див. наступний розділ). Видно, що мінімуми і максимуми концентрації, зображені на рис. 4, “зносяться по течії електронів", причому краї збурення зносяться швидше, ніж його центр. Наявність перпендикулярної до дрейфу електронів ненульової фазової швидкості плазмонних хвиль приводить до розпливання збурень, віддалених від диполя.

Аналогічний аналіз часово-просторових розподілів електронів можна провести для $z$-ї гілки частотної дисперсії. Для цього випадку замість рівняння (25) отримуємо

$n^{\prime(z)}\left(\mathbf{r}, \tau_{z}\right)=$

$=e^{\frac{\omega_{z}^{\prime \prime}}{\omega_{z}^{\prime}} \tau_{z}}\left[\left(K_{z}^{\prime} J_{x}^{\prime}(\mathbf{r})-K_{z}^{\prime \prime} J_{z}^{\prime \prime}(\mathbf{r})+J_{z}^{\prime}(\mathbf{r})\right) \cos \tau_{z}+\right.$

$\left.+\left(K_{z}^{\prime} J_{x}^{\prime \prime}(\mathbf{r})+K_{z}^{\prime \prime} J_{z}^{\prime}(\mathbf{r})+J_{z}^{\prime \prime}(\mathbf{r})\right) \sin \tau_{z}\right]$

Властивості цієї функції є дещо схожими з властивостями функції $n^{\prime(x)}\left(\mathbf{r}, \tau_{x}\right)$. Зокрема ця функція також 

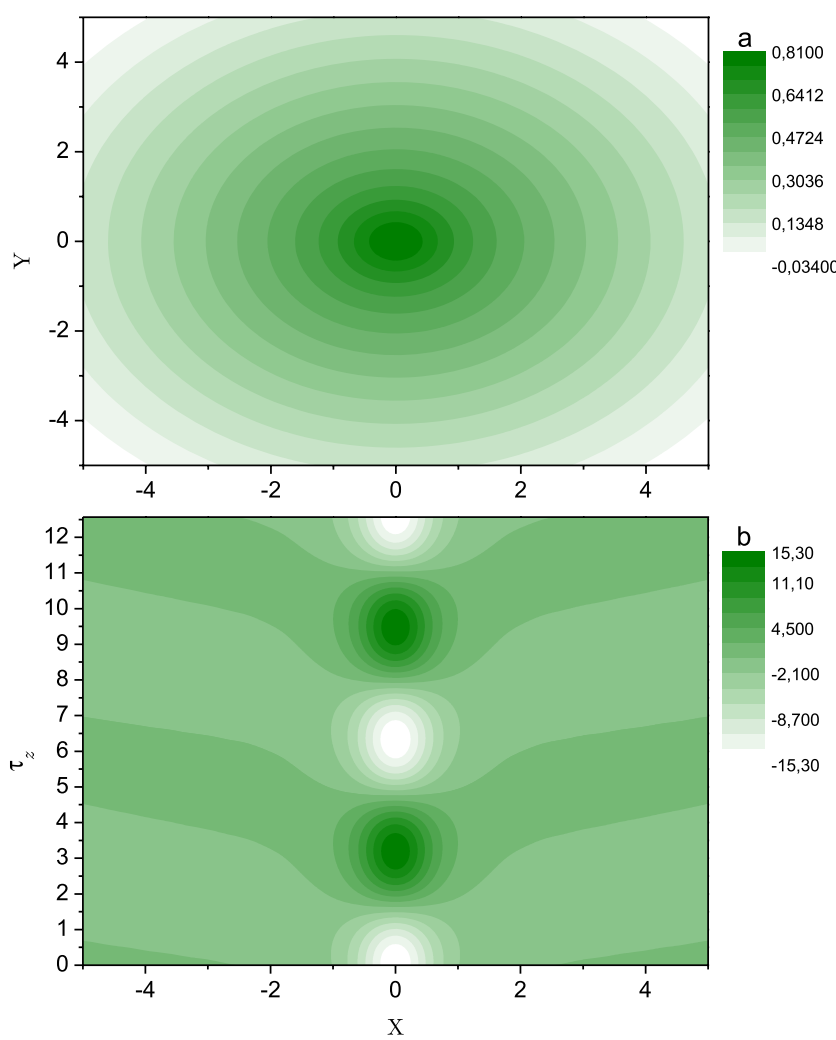

Рис. 6. Теж саме, що на рис. 4 для $z$-ї гілки частоти

є парною по $y$. Але, на відміну від $n^{\prime(x)}\left(\mathbf{r}, \tau_{x}\right)$, функція $n^{\prime(z)}\left(\mathbf{r}, \tau_{z}\right) \in$ парною функцією координати $x$ при $V_{0}=0$.

На рис. 6 проілюстровано поведінку концентрації електронів для z-ї гілки частоти при $V_{0}=0$ (диполь орієнтований паралельно осі $O Z$ ). Просторовий розподіл концентрації електронів у момент часу $\tau_{x}=3 \pi / 2$, який зображений на рис. $6, a$, має максимум, який розташовано під диполем, і є симетричним при заміні $x \rightarrow-x$ та $y \rightarrow-y$. На рис. $6, b$ продемонстровано близьку до періодичної поведінку збурення в часі.

На рис. 7 зображено теж саме, що на рис. 6, але в умовах існування дрейфу електронів зі швидкістю $V_{0} \approx 0,94$. У цьому випадку диполь теж орієнтований в площині $y=0$, але динаміка хвиль $є$ дещо складнішою, ніж та, що отримана вище для $x$-гілки. Збурення, які знаходяться поблизу диполя, рухаються проти течї електронів, а збурення, що далеко від диполя, рухаються за течією електронів. При $X \approx 3,5$ відбувається зміна характеру збурень, роль поширення хвиль стає домінуючою.

Розглянемо розв'язок інтегрального рівняння (14) для $y$-ї орієнтації диполя. Дійсна частина збурення
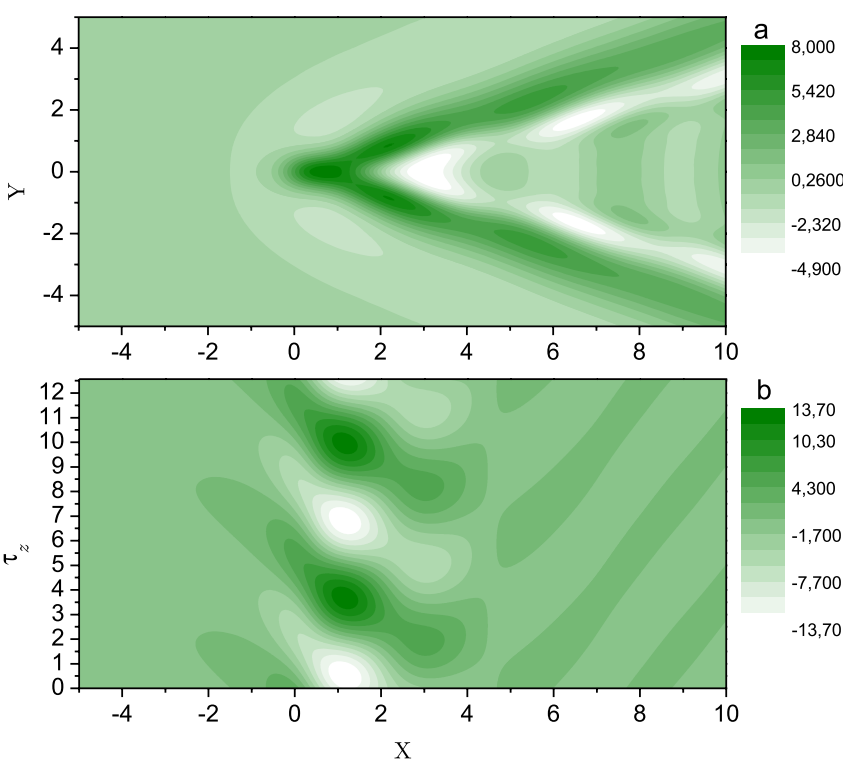

Рис. 7. Теж саме, що на рис. 5 для $z$-ї гілки частоти

концентрації електронів має вигляд

$n^{\prime(y)}\left(\mathbf{r}, \tau_{y}\right)=e^{\frac{\omega_{y}^{\prime \prime}}{\omega_{y}^{\prime}} \tau_{y}}\left[J_{y}^{\prime}(\mathbf{r}) \cos \tau_{y}+J_{y}^{\prime \prime}(\mathbf{r}) \sin \tau_{y}\right]$

де позначено

$J_{y}(\mathbf{r})=C B_{0} \int d^{2} k \frac{k k_{y}}{\Delta_{e}\left(\omega_{y}, k\right)} e^{-k h+i \mathbf{k r}}$

Властивості $n^{\prime(y)}\left(\mathbf{r}, \tau_{y}\right)$ є теж схожими 3 властивостями $n^{\prime(x)}\left(\mathbf{r}, \tau_{x}\right)$. При $V_{0}=0$ частотні гілки збігаються і щоб з $n^{\prime(x)}\left(\mathbf{r}, \tau_{x}\right)$ отримати $n^{\prime(y)}\left(\mathbf{r}, \tau_{y}\right)$, треба замінити $X \leftrightarrow Y$. Це саме стосується і рис. 4 . На відміну від $n^{\prime(x)}\left(\mathbf{r}, \tau_{x}\right)$, функція $n^{\prime(y)}\left(\mathbf{r}, \tau_{y}\right)$ є непарною функцією координати $y$ для будь-яких $V_{0}$, що пов'язано із сталою орієнтацією диполя паралельно до осі $O Y$. На рис. 8 проілюстровано координатну $(a)$ і координатно-часову $(b)$ залежності збурення концентрації електронів, що відповідає $y$-й гілці частоти при електронному дрейфі. При $Y=0$ підінтегральна функція інтеграла $J_{y}(\mathbf{r}) \in$ непарною, а отже, $n^{\prime(y)}\left(x, y=0, \tau_{y}\right)=0$. Тому рис. $8, b$ побудовано при $y=0,5$. Цей рисунок можна інтерпретувати подібно до рис. $7, b$ : збурення зносяться дрейфом електронів по течї, але при цьому мінімуми збурень переходять в їх максимуми і навпаки.

Таким чином, ми встановили, як поводять себе збурення двовимірних електронів у гібридній системі для різних типів розв'язків та залежно від відсутності чи наявності дрейфу електронів. 


\section{6. Поведінка диполя, індукованого в наночастинці}

Розглянемо поведінку поляризації наночастинки під час спільних електричних коливань гібридної системи. Ця поведінка описується динамікою наведеного дипольного моменту (5). Щоб знайти дипольний момент, потрібно розрахувати електричне поле електронів у точці знаходження диполя за допомогою визначення (9), першого співвідношення системи (12) та фур'є-компонент концентрації $n_{k}$, що для різних дисперсійних гілок були проаналізовані в попередньому розділі.

Розглянемо спочатку розв'язки, що пов'язані з $x$ ю гілкою дисперсії, коли компоненти дипольного моменту мають вигляд

$$
\left\{\begin{array}{l}
d_{x}\left(\omega_{x}\right)=-i C \frac{2 \pi e \beta_{0}\left(\omega_{x}\right)}{\kappa} \equiv \widetilde{C}_{x} \\
d_{y}\left(\omega_{x}\right)=0 \\
d_{z}\left(\omega_{x}\right)=i \widetilde{C}_{x} K_{x}
\end{array}\right.
$$

де $\widetilde{C}_{x}-$ нова довільна стала. Звідси знаходимо закон зміни компонент дипольного моменту у часі:

$$
\left\{\begin{array}{l}
D_{x}=e^{\frac{\omega_{x}^{\prime \prime}}{\omega_{x}^{\prime}} \tau_{x}}\left(\widetilde{C}_{x}^{\prime} \cos \tau_{x}+\widetilde{C}_{x}^{\prime \prime} \sin \tau_{x}\right), \\
D_{z}=-e^{\frac{\omega_{x}^{\prime \prime}}{\omega_{x}^{\prime}} \tau_{x}}\left[\left(\widetilde{C}_{x}^{\prime} K_{x}^{\prime \prime}+\widetilde{C}_{x}^{\prime \prime} K_{x}^{\prime}\right) \cos \tau_{x}+\right. \\
\left.+\left(\widetilde{C}_{x}^{\prime \prime} K_{x}^{\prime \prime}-\widetilde{C}_{x}^{\prime} K_{x}^{\prime}\right) \sin \tau_{x}\right] .
\end{array}\right.
$$

Система (29) є параметричним рівнянням еліпса: кінець вектора дипольного моменту рухається по еліптичній траєкторії у площині $y=0$. Неважко переконатися, що для $x$-ї частотної гілки дисперсї $K_{x}^{\prime}>0$ i $K_{x}^{\prime \prime}>0$, тому це обертання відбувається "проти годинникової стрілки". Оскільки диполь знаходиться в самоузгодженому полі з дрейфуючими електронами, то параметри цього еліпса залежать від дрейфової швидкості та частоти коливання диполя.

Константа $\widetilde{C}_{x}$ довільна, приймемо $\widetilde{C}_{x}=1 \mathrm{i}$, для простоти, вважатимемо $e^{\frac{\omega_{x}^{\prime \prime}}{\omega_{x}^{\prime}} \tau_{x}} \simeq 1$ (тобто будемо розглядати систему протягом декількох періодів). Тоді:

$$
\left\{\begin{array}{l}
D_{x}=\cos \tau_{x}, \\
D_{z}=K_{x}^{\prime} \sin \tau_{x}-K_{x}^{\prime \prime} \cos \tau_{x} .
\end{array}\right.
$$

Якщо виключити із системи (30) параметр $\tau_{x}$, то отримаємо рівняння цього еліпса у вигляді:

$a D_{x}^{2}+2 b D_{x} D_{z}+c D_{z}^{2}=1$

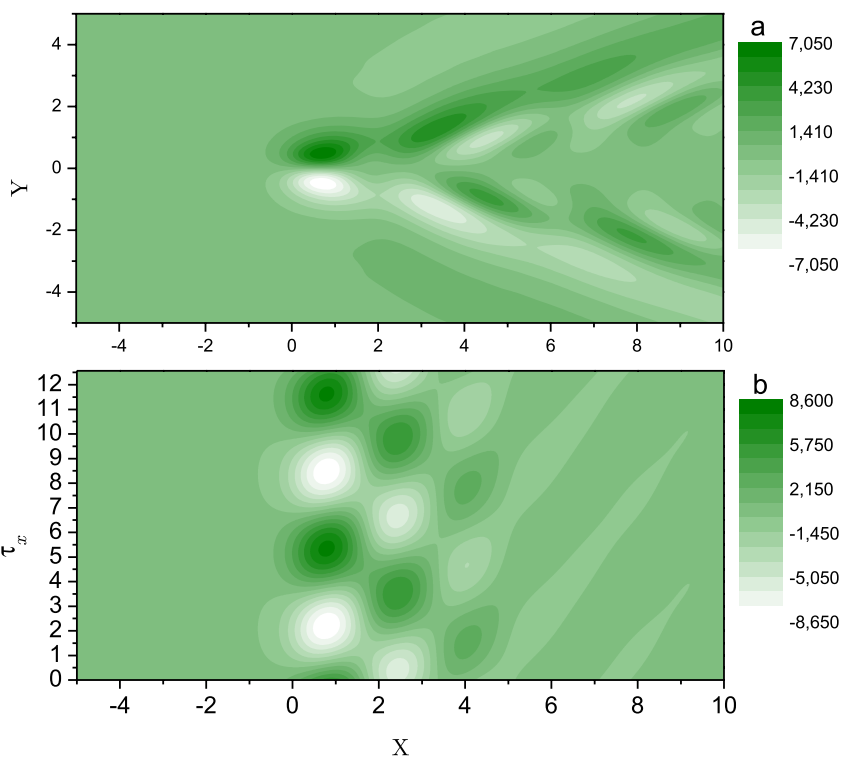

Рис. 8. Теж саме, що на рис. 5 для $y$-ї гілки частоти при $Y=0,5$

де $a=1+\left(K_{x}^{\prime \prime} / K_{x}^{\prime}\right)^{2}, b=K_{x}^{\prime \prime} / K_{x}^{\prime 2}$ та $c=1 / K_{x}^{\prime 2}$. Поворот системи координат на кут $\alpha_{x}$, що визначається рівнянням

$\operatorname{tg} \alpha_{x}=\frac{1-K_{x}^{\prime 2}-K_{x}^{\prime \prime^{2}}}{2 K_{x}^{\prime \prime}} \pm$

$\pm \sqrt{\left(\frac{1-K_{x}^{\prime 2}-K_{x}^{\prime \prime 2}}{2 K_{x}^{\prime \prime}}\right)^{2}+1}$

дозволяє отримати канонічне рівняння еліпса:

$\frac{D_{x_{0}}^{2}}{A^{2}}+\frac{D_{z_{0}}^{2}}{B^{2}}=1$

де $D_{x_{0}}, D_{z_{0}}-$ компоненти диполя в новій системі координат, $A, B$ є головними осями еліпса,

$A^{2}=\frac{1+\operatorname{tg}^{2} \alpha_{x}}{a+2 b \operatorname{tg} \alpha_{x}+c \operatorname{tg}^{2} \alpha_{x}}$

$B^{2}=\frac{1+\operatorname{tg}^{2} \alpha_{x}}{a \operatorname{tg}^{2} \alpha_{x}-2 b \operatorname{tg} \alpha_{x}+c}$.

За допомогою параметрів $A$ і $B$ вводиться ексцентриситет еліпса:

$\epsilon= \begin{cases}\sqrt{1-\frac{B^{2}}{A^{2}}}, & A>B, \\ \sqrt{1-\frac{A^{2}}{B^{2}}}, & A<B .\end{cases}$ 
a

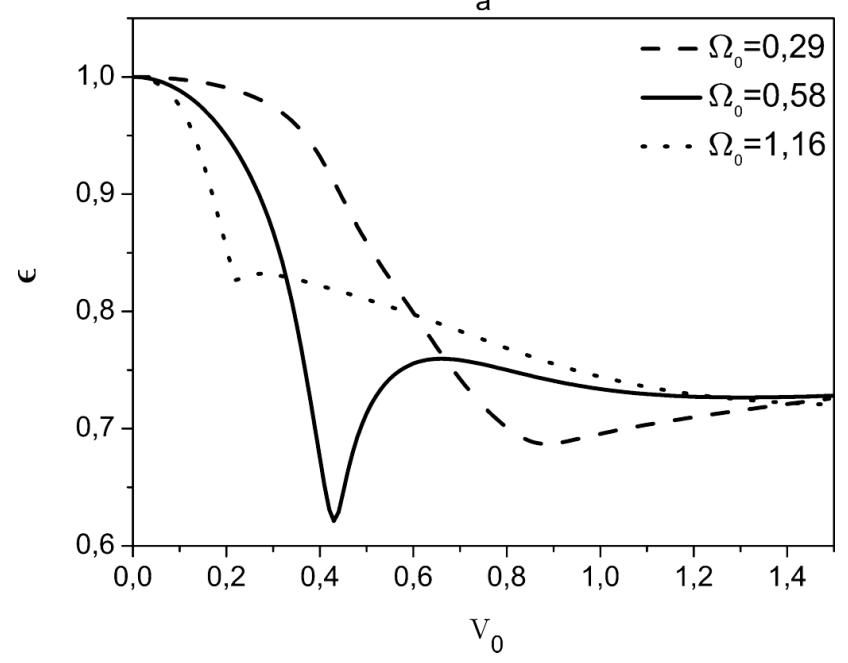

b

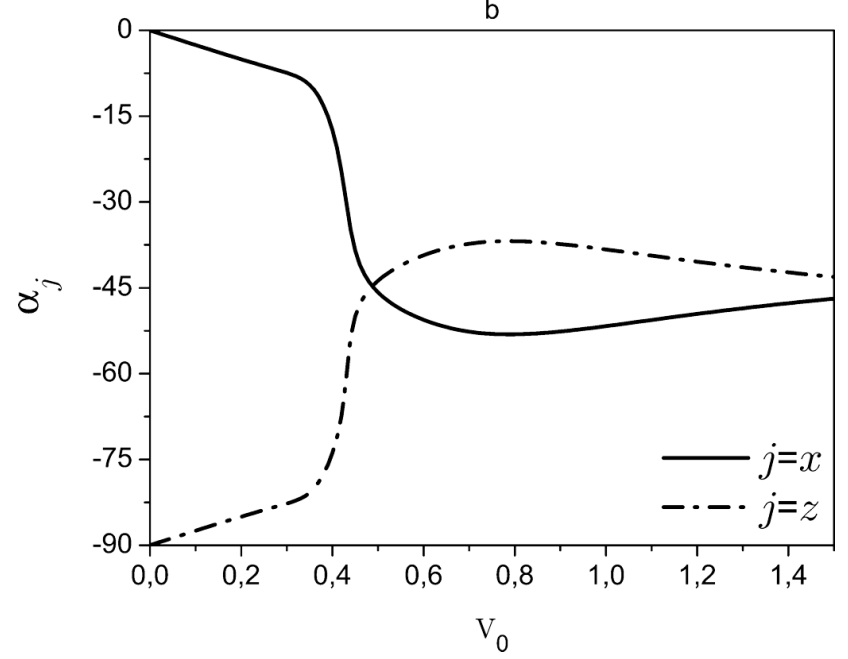

Рис. 9. Залежність ексцентриситету еліпса $\epsilon_{j}$ та кута повороту (в градусах) головних осей еліпса $\alpha_{j}$ від дрейфової швидкості

Значення $\epsilon$ варіюється від нуля до одиниці. Коли $\epsilon \rightarrow 0$, то еліпс переходить в коло, а коли $\epsilon \rightarrow 1$ еліпс переходить в лінію. Очевидно, що ексцентриситет еліпса, по якому обертається диполь, залежить від дрейфової швидкості та частоти коливань диполя, оскільки головні осі залежать від величини $K_{x}$. Зауважимо, що в системі координат, пов'язаних з головними осями, часова залежність диполя дуже проста:

$\left\{\begin{array}{l}D_{x_{0}}=A \cos \tau_{x}, \\ D_{z_{0}}=B \sin \tau_{x}\end{array}\right.$

Аналогічні формули можна отримати і для розв'язків, що пов'язані з z-ю гілкою дисперсії. В цьому випадку диполь обертається теж по еліпсу, але тепер уже "за годинниковою стрілкою". Головні осі еліпса залежать у цьому випадку від $K_{z}\left(\omega_{z}\right)$. Щоб отримати канонічне рівняння еліпса для $z$-ї гілки частоти, в рівняннях, що написані вище, потрібно зробити заміни: $a \leftrightarrow c, b \rightarrow-b, K_{x}\left(\omega_{x}\right) \rightarrow-K_{z}\left(\omega_{z}\right)$. У цьому випадку, ексцентриситет описується виразом (35), але змінюються головні осі $A \leftrightarrow B$ та кут $\alpha_{x} \rightarrow \alpha_{z}$. Ексцентриситет є однаковим для обох гілок дисперсії, оскільки $K_{x}\left(\Omega_{x}\right) \simeq-K_{z}\left(\Omega_{z}\right)$.

Що ж до $y$-ї орієнтації диполя, то ексцентриситет відповідного еліпса для цього випадку дорівнює одиниці для всіх $V_{0}$, що пов'язано з орієнтацією диполя строго паралельно осі $O Y$ для будь-яких $V_{0}$.

На рис. 9, а наведено залежність ексцентриситету $\epsilon$ від дрейфової швидкості електронів для трьох різних частот коливання диполя. Суцільною лінією зображено ексцентриситет, що відповідає такій же частоті, як на всіх попередніх рисунках, де ця частота фіксувалась, тобто $X \Omega_{0} \approx 0,58$. Дві інші лінії відповідають вдвоє меншій та вдвоє більшій частоті коливання диполя. 3 цього рисунка видно, що, коли дрейфова швидкість дорівнює нулю, то ексцентриситет дорівнює одиниці, тобто диполь коливається $з$ частотою $\Omega_{x}$ паралельно осі $O X$ та 3 частотою $\Omega_{z}$ паралельно осі $O Z$. На рис. $9, b$ при $V_{0}=0$ показано, що лінї, вздовж яких коливається диполь, перпендикулярні. При збільшенні $V_{0}$ ексцентриситет зменшується, що приводить до розгортання лінії в еліпс. Еліпс, який відповідає $x$-й гілці повертається "за годинниковою стрілкою", тому модуль кута, на який повертаються його осі щодо осі $O X$, росте. Інший еліпс обертається "проти годинникової стрілки", тому модуль його кута спадає. При деякій дрейфовій швидкості еліпси збігаються.

Подібну ситуацію спостерігаємо і при інших частотах коливань диполя. Криві на рис. 9 також показують, що ексцентриситети для різних частот мають схожу структуру і найменше значення $\epsilon$ реалізується для кривої, що відповідає $X \Omega_{0} \approx 0,58$. Для цього значення частоти в околі значення дрейфовій швидкості, яка відповідає мінімуму ексцентриситету $\left(V_{0} \approx 0,43\right)$, відбувається також різка зміна функції $R_{j}$, графік якої зображено на рис. 2. Також в околі $V_{0} \approx 0,43$ відбувається перетин функцій $\alpha_{x}$ та $\alpha_{z}$. Для інших частот такі мінімуми ексцентриситету наявні при інших дрейфових швидкостях і в околі цих мінімумів (а точніше в області різкого спаду ексцентриситету) поведінка функції $R_{j}$ теж різка. 
3'ясуємо фізичну причину нетривіальної поведінки індукованого диполя наночастинки. Для цього розглянемо електричне поле плазмонів у деякій віддаленій від 2DEG точці простору $x=y=0, z=h$. Закон дисперсії (13) має дві гілки, але для простоти розглянемо якусь одну гілку, опускаючи при цьому індекс у частоти і нехтуючи загасанням плазмонів. Нехай вдалося збудити плазмон з частотою $\omega(k)$ та двовимірним хвильовим вектором $\mathbf{k}=(k, 0)$. Тоді на відстані $h$ від початку координат він створить поле

$$
\left\{\begin{array}{l}
E_{x}=-i k\left|A_{0}\right| e^{-k h} e^{-i \omega t}, \\
E_{z}=k\left|A_{0}\right| e^{-k h} e^{-i \omega t}
\end{array}\right.
$$

де $\left|A_{0}\right|$ - довільна амплітуда. Фізичний зміст має дійсна частина знайденого поля, її компоненти є такими:

$$
\left\{\begin{array}{l}
E_{x}^{\prime}=-k\left|A_{0}\right| e^{-k h} \sin (\omega t), \\
E_{z}^{\prime}=k\left|A_{0}\right| e^{-k h} \cos (\omega t) .
\end{array}\right.
$$

Ми бачимо, що на деякій відстані від початку координат поле плазмонів обертається по колу. Очевидно, що дипольний момент наночастинки, який задано формулою (5), реагуючи на зовнішню силу теж буде обертатися під дією поля плазмонів. При спільних коливаннях гібридної системи збуджується не один, а багато плазмонів з різними k. Повне поле має більш складну часову залежність, що приводить до обертання диполя по еліпсу. Таким чином, динаміка поля плазмонів є ключем для розуміння поведінки поляризованості наночастинки.

Важливо, що поведінка наведеного диполя у часі може бути спостережувана на експерименті внаслідок особливостей випромінювання гібридної системи. Справді, розв'язавши проблему електростатичнопов'язаних наночастинки та двовимірного електронного газу, ми знайшли рух зарядів у гібридній системі. Руху поляризаційних зарядів у наночастинці та електронів у квантовій ямі відповідає деякий електричний струм, що залежить від координат та часу. Змінний у часі струм породжує випромінювання. Позначимо густину струму $\mathbf{j}(x, y, z, t)$. Тоді векторний потенціал поля випромінювання визначиться за допомогою формули [27]:

$\mathbf{A}(x, y, z, t)=\frac{1}{c_{0}} \int d x_{1} d y_{1} d z_{1} \frac{\mathbf{j}\left(x_{1}, y_{1}, z_{1}, t-\frac{R}{c_{0}}\right)}{R}$

де $c_{0}$ - швидкість світла, $R=\left[\left(x_{1}-x\right)^{2}+\left(y_{1}-y\right)^{2}+\left(z_{1}-\right.\right.$ $\left.z)^{2}\right]^{1 / 2}$. Використовуючи формулу (37), для дальньої зони випромінювання, отримуємо фур'є-компоненти векторного потенціалу у вигляді

$\mathbf{A}\left(x, y, z, \omega_{j}\right)=-\frac{i k_{0} \mathbf{d}\left(\omega_{j}\right) e^{-i \omega_{j} t+i k_{0} R_{0}}}{R_{0}}$,

де $R_{0}=\left[x^{2}+y^{2}+(z-h)^{2}\right]^{1 / 2}-$ відстань до точки спостереження, $k_{0}=\omega_{j} / c_{0}$. Частота $\omega_{j}$ належить одній з трьох частотних гілок. Дипольний момент, що визначає $\mathbf{A}$, формується самоузгодженою системою електронів та наночастинкою. Отже, характеристики випромінювання суттєво залежать від таких параметрів системи, як відстань від диполя до квантової ями, концентрація електронів, частота коливань диполя та дрейфова швидкість. При скінченних дрейфових швидкостях електронів наведений диполь обертається по еліпсу, і це повинно відображатися в поляризації випромінювання.

\section{7. Висновки}

Розглянуто гібридну систему, що складається з ізотропної наночастинки та гетероструктури 3 квантовою ямою. Вважається, що наночастинка поляризується в зовнішньому електричному полі і має характерні резонансні частоти в терагерцовому діапазоні. У цьому випадку в гібридній системі виникають спільні коливання поляризації наночастинки та плазмонів двовимірного електронного газу.

Отримано дисперсійні співвідношення для частот спільних коливань гібридної системи, зроблено їх аналіз, класифіковано можливі частотні гілки. Знайдено, що в системі виникає додаткове загасання коливань, яке має природу близьку до колективного загасання Ландау у плазмі. При дрейфі електронів додаткове загасання зменшується, а при достатньо великих дрейфових швидкостях у системі виникає нестійкість і наростання коливань для однієї з гілок дисперсії. Нестійкість виникає за рахунок енергї електричного струму. Інкремент електричної нестійкості збільшується при зменшенні відстані між диполем та електронами та збільшенні дрейфової швидкості.

Для чисельних ілюстрацій ефектів у ролі наночастинки розглянуто мілкий воднеподібний донор у бар'єрі гетероструктури на основі матеріалу InAs 3 бар'єрами GaAs.

Проаналізовано поведінку в часі та просторі збурень концентрації двовимірних електронів під час спільних коливань. Показано, що ця поведінка сут- 
тєво відрізняється для різних частотних гілок за відсутності та наявності дрейфу електронів.

Досліджено поляризаційні коливання наночастинки. Знайдено, що при ненульових дрейфових швидкостях наведений диполь характеризується складною динамікою. Зокрема, для двох із трьох гілок диполь обертається по еліптичних траєкторіях, що залежать від дрейфу електронів. Показано, що особливості поведінки поляризації наночастинки можуть бути спостережувані шляхом вимірювання випромінювання гібридної системи.

Практичний інтерес до нових явищ у гібридних системах може полягати в можливості збудження випромінювання наночастинок струмом та електричної генерації ТГц випромінювання. Також ці явища можуть бути використані для контрольованої полем адресації до індивідуальних наночастинок, що є ключовою проблемою для реалізації квантових обчислень [28].

Автори висловлюють щиру подяку М. В. Стрісі за уважне прочитання даної роботи та цінні зауваження. Робота частково підтримана державною цільовою науково-технічною програмою "Нанотехнології та наноматеріали".

1. P. Bakshi and K. Kempa, Superlat. Microstruct 17, 363 (1995).

2. S.A. Mikhailov, Recent Res. Devel. Appl. Phys. 2, 65 (1999).

3. B.Y.K. Hu and J.W. Wilkins, Phys. Rev. B 41, 10706 (1990).

4. Z.S. Gribnikov, N.Z. Vagidov, and V.V. Mitin, J. Appl. Phys. 88, 6736 (2000).

5. K. Kempa, P. Bakshi, and E. Gornik, Phys. Rev. B 54, 8231 (1996).

6. M. Dyakonov and M.S. Shur, Phys. Rev. Lett. 71, 2465 (1993); Appl. Phys. Lett. 87, 111501 (2005).

7. W. Knap, J. Lusakowski, T. Parenty, S. Bollaert, A. Cappy, V.V. Popov, and M.S. Shur, Appl. Phys. Lett. 84, 2331 (2004).

8. J. Lusakowski, W. Knap, N. Dyakonova, L. Varani, J. Mateos, T. Gonzalez, Y. Roelens, S. Bollaert, and A. Cappy, J. Appl. Phys. 97, 064307 (2005); N. Dyakonova, A. El Fatimy, J. Lusakowski, W. Knap, M.I. Dyakonov, M.-A. Poisson, E. Morvan, S. Bollaert, A. Shchepetov, Y. Roelens, Ch. Gaquiere, D. Theron, and A. Cappy, Appl. Phys. Lett. 88, 141906 (2006).
9. T. Otsuji, Y.M. Meziani, T. Nishimura, T. Suemitsu, W. Knap, E. Sano, T. Asano and V.V. Popov, J. Phys.: Condens. Matter 20, 384206 (2008).

10. T. Demel, D. Heitman et al., Phys. Rev. Lett. 64, 788 (1990).

11. Ch. Sikorski and U. Merkt, Phys. Rev. Lett. 62, 2164 (1989); B. Meurer, D. Heitmann, and K. Ploog, Phys. Rev. Lett. 68, 1371 (1992); D. Heitmann, J.P. Kotthaus, Phys. Today, 48, 56 (1993).

12. S.M. Reimann and M. Manninen, Rev. Mod. Phys. 74, 1283 (2002).

13. C.P. Garcia, S. Kalliakos, V. Pellegrini, A. Pinczuk, B.S. Dennis, L.N. Pfeiffer, and K.W. West, Appl. Phys. Lett. 88, 113105 (2006).

14. B. Yu, F. Zeng et al., Biophys. J. 86, 1649 (2004).

15. V.N. Maistrenko, S.V. Sapernikova et al., J. Analyt. Chem. 55, 586 (2000).

16. R. Balu, H. Zhang et al., Biophys. J. 94, 3217 (2008).

17. J. Burghoon, T.O. Klaassen, and W.T. Wenchebach, Semicond. Sci. Technol. 9, 30 (1994).

18. A.J. Kalkman, H.P.M. Pellemans, T.O. Klaassen, and W.T. Wencheback, Int. J. Infrared Millim. Waves 17, 569 (1996).

19. D.G. Allen, M.S. Sherwin, and C.R. Stanley, Phys. Rev. B 72, 035302 (2005).

20. S.M. Kukhtaruk, Ukr. J. Phys. 55, 8, 916 (2010).

21. А.С. Давыдов, Квантовая механика (Физматгиз, Москва, 1963).

22. Е.М. Лифшиц, Л.П. Питаевский, Физическая кинетика (Наука, Москва, 1979), т. 10.

23. V.V. Mitin, V.A. Kochelap, and M.A. Stroscio, Quantum Heterostructures (Cambridge University Press, New York, 1999).

24. F. Kuchar, G. Bauer, and H. Hillbrand, Phys. Status Solidi A 17, 491 (1973).

25. A. Krotkus and Z. Dobrovolskis, Electrical Conductivity of Narrow-Gap Semiconductors (Mokslas, Vilnus, 1988) (in Russian).

26. W.T. Masselink, Semicond. Sci. Technol. 4, 503 (1989).

27. Л.Д. Ландау, Е.М. Лифшиц, Теория поля (Наука, Москва, 1988), т. 2.

ISSN 2071-0194. Укр. фіз. журн. 2012. Т. 5\%, №3 
28. M.A. Nielsen and I.L. Chuang, Quantum Computation and Quantum Information (Cambridge University Press, Cambridge, UK, 2000).

Одержано 22.04.11

\section{ВЗАИМОДЕЙСТВИЕ ИЗОТРОПНОЙ НАНОЧАСТИЦЫ С ДРЕЙФУЮЩИМИ ЭЛЕКТРОНАМИ В КВАНТОВОЙ ЯМЕ}

\section{B.A. Кочелап, C.H. Kухтарук}

$\mathrm{P}$ е $з$ ю м е

Рассмотрены гибридные системы, состоящие из наночастицы и полупроводниковой гетероструктуры с квантовой ямой. Наночастица такова, что поляризуется в постороннем электрическом поле. Обоснована и сформулирована модель гибридной системы. Получены точные решения уравнений. Найденные частоты колебаний зарядов гибридной системы и их дополнительное затухание обусловлены, взаимодействием диполя с плазмонами. Природа дополнительного затухания подобна затуханию Ландау. Проанализировано поведение во времени и пространстве возмущений концентрации двухмерных электронов. Исследованы поляризационные колебания наночастицы. Найдено, что при ненулевых дрейфовых скоростях наведенная поляризация характеризуется сложной динамикой. В частности для двух из трех ветвей частотной дисперсии вектор поляризации вращается по эллиптическим траекториям. В случае, когда к квантовой яме приложено поле и течет ток, затухание изменяется на нарастание колебаний гибридной системы во времени, которое отвечает электрической неустойчивости гибридной системы. Новые явления в гибридных системах могут быть применены для возбуждения излучения наночастиц током, для электрической генерации излучения в терагерцовой области спектра.

\section{INTERACTION BETWEEN AN ISOTROPIC NANOPARTICLE AND DRIFTING ELECTRONS IN A QUANTUM WELL}

\author{
V.A. Kochelap, S.M. Kukhtaruk
}

V. Lashkaryov Institute of Semiconductor Physics, Nat. Acad. of Sci. of Ukraine, (41, Prosp. Nauky, Kyiv 03680, Ukraine; e-mail:kukhtaruk@gmail.com)

$\mathrm{S} \mathrm{u} \mathrm{m} \mathrm{m} \mathrm{a} \mathrm{r} \mathrm{y}$

A hybrid system composed of an isotropic nanoparticle and a semiconductor heterostructure with a quantum well has been considered. The nanoparticle is supposed to be polarizable in an external electric field. A theoretical model of the hybrid system is substantiated and formulated. Exact solutions of the model equations are obtained. The frequencies of charge oscillations in the hybrid system and their damping owing to the dipole-plasmon interaction are found, the damping mechanism being similar to that of Landau damping. The space-time behavior of concentration perturbations in the two-dimensional electron gas is analyzed, and the polarization oscillations of a nanoparticle are studied. The induced polarization of a nanoparticle at nonzero electron drift velocities is found to have a complicated dynamics. In particular, the polarization vector circulates along elliptic trajectories for two of three frequency dispersion branches. If the electric current flows through the quantum well due to an applied electric field, the damping of oscillations in the hybrid system is replaced by their growth in time, which corresponds to the electric instability of the system. New phenomena in hybrid systems can be used to excite the emission of nanoparticles by an electric current and to electrically stimulate the emission in the terahertz spectral range. 